\title{
Epigenetik Değişiklikler ve Mesane Kanseri Arasındaki ilişki
}

\section{The Relationship between Bladder Cancer and Epigenetic Alterations}

\author{
Dr. Ata Özen, Dr. Ali Ülgen, Dr. Cavit Can \\ Osmangazi Üniversitesi Tıp Fakültesi, Üroloji Anabilim Dalı, Eskișehir, Türkiye
}

\begin{abstract}
Öz
Mesane tümörleri üriner sistemin en sık görülen kanserlerinden olup olguların yaklaşık \%70'i düşük dereceli ve kasa invaze olmayan tümörlerdir. Mesane kanseri gibi heterojen bir yapıya sahip tümörlerde histolojik göstergelerdeki yetersizlik nedeniyle, araştırmacılar genetik ve moleküler belirteçlere yönelmişlerdir. Ayrıca kanser biyolojisinde epigenetik değişikliklerin rolünün diğer hücresel değişikliklere göre daha fazla rol oynadığı da gösterilmiştir. Epigenetik değişiklikler DNA metilasyonu, mikro RNA regülasyonu ve histon modifikasyonu olmak üzere üç ana başlık altında incelenir. Literatürde birçok epigenetik değişikliğin hastalığın erken tanısı, progresyonu ve hasta prognozu, tümör rekürrensi, erken relaps, ileri patolojik evre, hastalığa spesifik sağkalım ile ilişkili olduğu gösterilmiştir. Epigenetik değişikliklerin anlaşılması ile gelecekte hastalarla ilgili daha iyi sonuçlar elde edilecektir. Anahtar Kelimeler: Mesane kanseri, epigenetik, tanı, prognoz
\end{abstract}

\begin{abstract}
Bladder cancer is one of the most common cancers of urinary system and approximately $70 \%$ of the cases are low grade and non-muscle invasive. Because of the histological indicator inadequacy of heterogeneous tumors like bladder cancer, researchers tend to look into genetic and molecular markers. Furthermore, role of epigenetic changes in cancer biology to be more distinctive than other cellular changes was shown. Epigenetic changes include 3 main titles; DNA methylation, micro RNA regulation and histone modification. In the literature, many epigenetic changes were found to be associated with early detection of the disease, progression, patient prognosis, tumor recurrence, early relapse, higher pathologic stage, disease-specific survival. With the understanding of epigenetic changes better patient outcomes will be achieved in the future.
\end{abstract}

Keywords: Bladder cancer, epigenetic, diagnosis, prognosis

\section{Giriş}

Mesane tümörleri üriner sistemin en sık görülen kanserlerinden olup kadınlarda tüm malign tümörlerin \%2-3'ünü, erkeklerde ise \%6-8'ini oluşturur. Erkeklerde kadınlardan 4 kat fazla ve en sık 6 ve 7 . dekatlarda görülür (1). Mesane tümörlerinin, \%90'dan fazlası değişici epitel hücreli karsinomdur ve olguların yaklaşık \%70'i düşük dereceli ve kasa invaze olmayan tümörlerdir (2).

Onkolojide düşük ve yüksek riskli hastaların tanımlanması en önemli sorundur. Hastalığı, progresyondan ve mortaliteden korumak amacıyla agresif yöntemlerle zamanında tedavisi ne kadar önemliyse, gereksiz rezeksiyon ve ilaç uygulamaları, bunların olası yan etkileri ve komplikasyonları gibi işlemlerle hayat kalitesini bozmamak ve ekonomik yükü artırmamak da bir o kadar önemlidir. Günümüzde kas invaziv olmayan mesane tümörlü hastaların takibi halen aralıklı olarak sistoskopi ile yapılmaktadır. Sistoskopinin invaziv bir işlem olması nedeniyle non-invaziv tanı yöntemleri üzerine araştırmalar devam etmektedir. Yine mesane tümörünün doğal seyrini öngörmede tümörün histolojik tipi, evresi ve farklılaşma derecesi, hemen tüm malignitelerde olduğu gibi doğal seyire doğrudan etki eden faktörlerdir. Ancak, mesane kanseri gibi, heterojen bir yapıya sahip tümörlerde klasik belirteçlerle doğal seyri öngörebilmek yeterli olmayabilir. Tümörün erken tanısı, rekürrens ve progresyon gelişebilecek risk grubundaki hastaların belirlenmesi günümüzde klasik metotlar olan sitoloji, histopatoloji, tümör nod metastaz evrelemesi ile tam olarak belirlenememektedir. Bu yüzden araştırmacılar doğal seyri öngörebilmek için ve hastalığın non-invaziv metotlarla takibini yapabilmek için genetik ve moleküler belirteçlere yönelmişlerdir.

Kanser hücresini, normal hücreden ayıran temel özellikler; apoptotik mekanizmalardan kurtulma yeteneği, kanser hücresinin kendisine yönelik gelişme sinyalleri sağlayabilmesi ve gelişimi önleyici sinyallere karşı duyarsız olması, anjiyogenetik kapasite, sınırsız çoğalma gücü, doku invazyonu ve metastaz yapabilme becerisi olarak sayılabilir. Bu şekilde değerlendirildiğinde tümör oluşumu, karsinojenik olayları başlatacak kromozomal değişimler, hücre döngüsü ve apoptotik sürecin bozulmasına bağlı tümör proliferasyonu ve metastaz olarak ifade edilebilir. Mesane tümöründe de olduğu gibi tümörlerin büyük çoğunluğu bazı genetik ve epigenetik değişikliklerin etkilediği proto- 
onkojenlerdeki aktivasyon ya da tümör süpresör genlerdeki inaktivasyon sonucu ortaya çıkmaktadır (3).

Ürotelyal karsinomların genetik özelliklerine bakıldığında iki ayrı yolak dikkati çekmektedir. Papiller lezyonlar hiperplazik ürotelyumdan köken alırken, invaziv tümörler ise displazik ürotelyumdan gelişmektedir. Papiller tümörler RAF/MEK/ERK ve PIK3CA yolağındaki genlerin değişimi ile ilgilidir (örneğin; FGFR3). Non-papiller invaziv tümörler ise p53 ve pRb yolağındaki değişimlerle oluşur. Her iki yolağın da başlangııında 9. kromozomda değişimler olduğu düşünülmektedir (4). Çok sayıda kromozomal değişiklik tanımlanmıştır. Özellikle 9. kromozomdaki kayıplar hem yüzeyel hem de invaziv tümörlerde gösterilmişken $3 p$, $5 p$ ve $17 p^{\prime}$ deki kayıplar sadece invaziv tümörlerde tanımlanmıştır (5). Ancak kromozomlarda kayıp olmadan da bazı genlerin aktivasyonu ya da süpresyonu ile tümör gelişimi arasında ilişki saptanmışıı. Ayrıca klasik genetik çalışmalar ile monozigotik ikizlerde ve klonlanan hayvan çalışmalarında farklı fenotiplerin ortaya çıkması ya da hastalıklara yatkınığın farklı olması açıklanamamaktadır. Bu duruma epigenetik süreçlerin genomda bazı genlerin aktivitelerini baskılayarak neden olabileceği düşünülmektedir (6).

Epigenetik

DNA dizi değişikliği olmadan mayotik ve/veya mitotik olarak kalıtılabilen gen aktivitesindeki değişiklikler epigenetik olarak tanımlanmıştır. Kanser gelişimindeki tek faktörün gen bütünlüğünün bozulmuş olmasından kaynaklanmadığı günümüzde bilinmektedir. Ayrıca kanser biyolojisinde epigenetik değişikliklerin rolünün diğer hücresel değişikliklere göre daha fazla rol oynadığı da gösterilmiştir. Genin düzenleyici bölgesinde meydana gelen patolojik epigenetik değişiklikler de gen fonksiyonunda bozulmaya yol açarak kanser gelişimine yol açmaktadır. Büyüme düzenleyici genlerin aktivasyonu ve tümör süpresör genlerin baskılanması genetik değişikliklerin etkilerini taklit ederek kanser gelişiminde rol oynar $(7,8)$.

Epigenetik, DNA metilasyonu, mikro RNA regülasyonu ve histon modifikasyonu olmak üzere üç ana başlık altında incelenir $(9,10)$.

\section{DNA Metilasyonu (Hipermetilasyon ve Hipometilasyon)}

Epigenetik değişiklikler içinde en bilineni ve üzerinde en çok çalışma yapılanı DNA metilasyonudur $(9,10)$. Metil vericisi olarak S-adenozil methioninin kullanıldığı DNA metiltransferaz (DNMT) enzimi tarafından katalize edilen ve sonucunda 5-metilsitozinin oluştuğu bir reaksiyondur $(11,12)$. Memelilerde 4 farklı DNMT enzimi (DNMT1, DNMT3A, DNMT3B, DNMT3L) bilinmektedir ve kanser gelişiminde en önemli olanı DNMT1'dir (13). Metilasyon genellikle sitozini takip eden guanin nükleotidlerinin bulunduğu konsantre DNA içindeki kümelenmiş $\mathrm{CpG}$ adacıklarında meydana gelir. İnsan geninin 5' ucunda bulunan ve promoter bölge denilen alan (düzenleyici) unmetile durumda iken gen aktiftir ve ekspresyona izin verir $(11,12)$. Tümör süpresör genlerde görülen bu değişiklik genin inaktif hale geçmesine yol açar. Inaktivasyon hücre çoğalması sonucunda ortaya çıkan yeni jenerasyon hücrelerde de devam eder. Bu epigenetik değişiklik, gen baskılanmasına yol açan diğer nedenlerden olan mutasyon veya delesyona alternatif bir yolak olarak karşımıza çıkar. Fizyolojik hipermetilasyona örnek olarak kadınlarda X kromozomunun sessiz kopyası örnek verilebilir $(14,15)$. DNA promoter metilasyonunun transkripsiyonu nasıl engellediği net olarak bilinmemektedir. Direkt olarak promoter bölge yakınında ya da içinde bulunan transkripsiyon aktivatörlerinin oluşumunu engelleyerek veya indirekt olarak metilsitozin bağlayan proteinleri arttırarak transkripsiyonu engellediği düşünülmektedir. Sitozin bağlayıcı proteinler DNMT ve histon deasetilazları içeren büyük protein kompleksleridir ve kromatin konformasyonunda değişikliğe yol açarak gen transkripsiyonunu engellerler $(14,16,17,18)$.

DNA metilasyonu çeşitli hücresel olaylarda kritik öneme sahiptir ve bu değişiklikler lokal ve global olarak kanser gelişiminde rol oynar $(16,19)$. Bu hücresel olayların doğal seyri epigenetik değişikliklere ve derecesine bağlıdır. DNA'nın hipermetilasyonu gende istenmeyen suskunluğa yol açarken, hipometilasyonu onkojenlerin aktivasyonuna ve genetik dayanıksılığa neden olur $(8,19,20)$. DNA'ya bağlı metil gruplarını uzaklaştıran enzimler demetilaz enzimleridir. Hipermetilasyona benzer şekilde hipometilasyon da kanser riski ile ilişkilidir (10). DNA'daki metilasyon değişikliklerine neden olan mekanizma halen bilinmemekle birlikte birçok çalışma metilasyon değişikliklerinin karsinogenezin erken safhalarında ortaya çıktı̆̆ı ve bunun kanser gelişimindeki ilk ortaya çıkan yıkıcı mekanizmalardan olduğu gösterilmiştir $(19,21)$.

Metilasyonun diğer moleküler biyomarkerlere göre avantajları da şöyle sıralanabilir. Birincisi kanserli DNA'daki metilasyon değişikliği birkaç seçilmiş DNA lokusunda meydana gelmektedir ve bu bütün epigenomun durumunu yansıtmaktadır. İkincisi hipermetilasyon her zaman aynı genomik bölgede oluşmaktadır buyüzden tespiti kolaydır. Üçüncüsü ise hipermetilasyon DNA'dan çalışlabildiği için RNA kullanımı ve immünohistokimyasal tekniklerin zorluklarından kaçınıımış olur (22).

\section{Histon Modifikasyonları ve Kromatinin Yeniden Şekillenmesi} (Remodeling)

Kromatinin en küçük yapı birimi olan nükleozom, DNA çift sarmalı tarafından sarılmış ve histon proteinlerinden oluşan bir komplekstir. Her nükleozom 8 histon molekülü barındırır. Bunlar her birinden ikişer tane olmak üzere $\mathrm{H} 2 \mathrm{~A}, \mathrm{H} 2 \mathrm{~B}, \mathrm{H} 3$ ve $\mathrm{H} 4{ }^{\prime}$ tür. Bu biyomoleküller DNA'yı fiziksel etkilerden korumanın yanında transkripsiyonel düzenlemede, onarım ve replikasyonda önemli etkiye sahiptirler $(23,24,25)$. Histonlar ve DNA molekülü genlerin aktivasyonunda ya da baskılanmasında düzenleyici rol oynarlar. Böylelikle sentezlenen ya da sentezlenmeyen proteinler diğer genlerin aktivasyonuna ya da baskılanmasına yol açarak zincir reaksiyon etkisi oluştururlar. Histon kuyrukları DNA'ya doğru çıkıntı yaparak translasyon sonrası biyokimyasal değişiklikleri etkinleştiren (asetilasyon, glikozilasyon, fosforilasyon gibi) ve spesifik aminoasitler aracilı̆ıyla translasyonel ve yapısal değişikliklere yol açan bir histon koduna sahiptir. En iyi bilinen histon modifikasyonu asetilasyondur. Asetilasyon histonların DNA'ya afinitesini azaltır ve kromatin konformasyonunun açılmasına ve metilasyonuna neden olur. Bunun sonucunda bazı spesifik aminoasitlerin etkisiyle transkripsiyon baskılanır veya aktive edilir. Transkripsiyonun aktivasyonu histon 3 molekülündeki 4,36 ve 79. lizinin metilasyonu sonucu ortaya çıkarken, baskılanması ise histon 3'ün 9 ve 27. lizini ile histon $4^{\prime}$ ün 20 . lizininin metilasyonu sonucu ortaya çıkar. Histon modifikasyonları, histon asetiltransferaz, deasetilaz, metiltransferaz, demetilaz gibi değişik substratlara spesifik bir grup enzim tarafından düzenlenir $(23,24,25)$. Histon modifikasyonları genomik imprintingde, 
embriyonik kök hücrelerin gelişiminde ve değişiminde rol oynar $(23,26)$. Malign hücrelerde genom genelinde histon değişiklikleri haritalanmıştır; ancak günümüzde tümör gelişimindeki etkisi DNA metilasyonuna göre daha az aydınlatılabilmiştir $(6,19)$.

\section{MicroRNA Regülasyonu}

MicroRNA'lar 25 nükleotidden oluşan, nükleusta sentezlenip sitoplazmaya salınan mRNA'lara bağlanıp ekspresyonunun değişimine yol açan küçük biyomoleküllerdir $(27,28)$. Her bir mikroRNA pek çok mRNA'yı etkileyebildiği gibi her bir mRNA da pek çok mikroRNA'nın etkisi altındadır (29).

Tümör hücrelerinde mikroRNA disregülasyonu görülebilir ve sonucunda hücrede diferansiyasyon ve proliferasyon ortaya çıkar. MikroRNA salınımı fazla olduğunda onkojenlere benzer bir etki ortaya çıkarken, salınımı azaldığında tümör süpresör genlerin etkisini taklit eder $(27,28)$. Kanser gelişimindeki rolleri hedef genlerine bağlıdır. MikroRNA salınımındaki değişiklikler transkripsiyon faktörlerinin ekspresyonunda değişikliğe yol açarak karsinogenezde rol oynar $(27,28,30)$. Ayrıca mikroRNA'ların diğer hedef noktaları da post-transkripsiyonel enzimler, DNA metilasyonu ile ilgili genler, histon modifikasyonlarını düzenleyici genlerdir. Bu başlıca epigenetik mekanizmaların birbirleriyle olan karmaşık ilişkilerini de göstermektedir $(27,28)$.

\section{Mesane Tümörü Tanısında Epigenetik Belirteçlerin Rolü}

Mesane tümörünün tanısında epigenetik yöntemlerin kullanımı üzerine umut verici çalışmalar yapılmaktadır. Bu yöntemlerin sistoskopi gibi invaziv yöntemleri azaltabileceği düşünülmektedir. Çünkü DNA analizleri, polimeraz zincir reaksiyonu (PCR) ile kolaylıkla yapılabilmekte ve genetik anormallikler ortaya çıkarılabilmektedir (31). En iyi bilinen yöntem metilasyon varlığını ya da yokluğunu gösteren metilasyon spesifik PCR'dir. Bu yöntemle çok az miktardaki DNA örneklerinden çeşitli belirteçlere bakılabilmekte ve DNA materyali mesane tümörlü hastaların idrarından tespit edilebilmektedir (32). Ancak tek bir gen üzerinden yapılan çalışmalarda yeterli başarı sağlanamadığından genellikle birkaç genden oluşan gen panelleri üzerinde durulmuştur.

Özellikle mesane tümörlü hastaların idrar örneklerinde TWIST-1 ve NID-2 hipermetilasyonun sitolojiyle karşılaştırıldığı çalışmada oldukça etkileyici sonuçlara ulaşılmıştır. Dört yüz doksan altı mesane tümörlü hastanın idrar örneklerinin incelendiği çalışmada erken evredeki tümörlerde bile bu iki genin sıklıkla metile olduğu görülmüştür. Duyarlıı̆ğı $\% 90$ olarak bulunmuş ve sitolojinin duyarılı̆̆ı ile (\%48) karşılaştırıldığında oldukça yüksek olduğu görülmüştür. Yine özgüllüğü de sitolojiyle karşılaştırılabilir düzeyde bulunmuştur (\%93-\%96). Çalışma sonucunda bu iki gen ile mesane tümörünün tanısının \%90'ın üzerinde özgüllük ve duyarlılık ile non-invaziv olarak konulabileceği belirtilmiştir (33).

Chung ve ark.'nın (34) çalışmasında ise idrardan çalışılan 2 gen grubu bildirilmiştir. Illk gruptaki MYO3A, CA10, NKX6-2 ve $\mathrm{DBC} 1$ veya SOX11'in mesane kanserini saptamadaki duyarlılığı \%81 ve özgüllüğü \%97 iken MYO3A, CA10, NKX6-2 ve DBC1 veya PENK içeren ikinci grupta duyarlılığı \%85, özgüllüğü \%95 olarak bulunmuştur.

Mesane tümörlü hastaların idrar örneklerinde RAR $\beta$, DAPK, E-cadherin ve p16 gen panelindeki genlerden en az birinin hipermetilasyonu \%90,9 olarak saptanmıştır. Sitolojide ise kanserli hücrelerin saptanma oranı $\% 45,5$ olarak bulunmuştur. Yine DAPK, E-cadherin ve p16'nın özgüllüğü \%100 olarak saptanmıştır (35). Dulaimi ve ark. (36) mesane tümörlü hastaların idrar örneklerinde APC, RASSF1A ve p14ARF genleri ile yaptığı çalışmada da hipermetilasyonunun tümörü tespitinde sitolojiye üstün olduğu vurgulanmıştır (\%91-\%50).

Idrar sedimentinden mesane kanserini doğru bir şekilde saptayan bir diğer gen paneli de GDF15, TMEFF2 ve VIM'dir. Bu panel ile idrar örneklerinde \%90 özgüllük ile birlikte \%94 duyarlılık saptanmış olup, mesane kanserini hem sağlıklı bireylerden hem de böbrek ve prostat kanseri hastalarından ayırt edebilmesi de avantajlarından birisi olarak değerlendirilmiştir. Bu yüzden idrar örneklerinde rutin mesane kanseri taraması için kolaylıkla kullanılabileceği söylenmektedir (37).

Hipermetilasyona benzer şekilde DNA hipometilasyonu da artmış kanser riski ile ilişkilidir. DNA hipometilasyonu da mesane kanseri için potansiyel bir biyomarkerdir. LINE-1 geni bunlardan biridir. Ama bu epigenetik değişiklik ile mesane kanseri arasındaki ilişki tam net değildir ve DNA hipometilasyonunun daha çok tanı sonrası belirteç olarak yararlı olduğu gösterilmiştir (38).

Mesane kanserinin tanısında diğer epigenetik değişikliklerin etkisini gösteren çalışmalar daha azdır. MikroRNA değişikliklerinden olan mikroRNA-126 ve mikroRNA-182'nin idrar seviyelerinin mesane kanserini $\% 82$ özgüllük ve $\% 72$ duyarlıık ile belirlediği gösterilmiştir (39). MikroRNA-141'in malign doku örneklerinin $\% 91$ 'inde up-regüle olurken mikroRNA-200c ve mikroRNA-30b'nin sırasıyla \%79 ve \%64 aşırı eksprese edildiği bildirilmiştir (40). Yine mesane kanseri dokularında normal dokulara göre histon modifikasyonlarından olan EZH2 ve LSD1 ekspresyonunun anlamlı derecede artmış olduğu bulunmuş ancak bunun idrar örneklerindeki doğrulaması yapılamamıştır $(41,42)$.

Çeşitli gen panelleri ile çalısmalar mesane tümörünün idrar örneklerinde, yıkama sıvılarında non-invaziv olarak tespit edilebilmesi için devam etmektedir. Duyarlılık ve özgüllük bakımından en iyi gen panellerinin oluşturulması amaçlanmaktadır.

\section{Epigenetik Belirteçlerin Prognostik Önemi}

Son dönemde yapılan çalışmalar epigenetik değişikliklerin hastalığın prognozu üzerine de etkisi olabileceğini göstermektedir. RUNX-3 metilasyonun tümör oluşumunda ve hatta sigara içiminde semptomlar ortaya çıkmadan önce risk altındaki popülasyonu belirlediği öne sürülmüştür (43). RUNX-3 metilasyonuna bağıı inaktivasyonun kanser için 100 kat artmış risk oluşturduğu bildirilmiştir. Ayrıca tümörün evresi, rekürrens ve progresyon ile ilişkili olduğu gösterilmiştir (44). Başka bir çalışmada TIMP-3 metilasyonun hastalı̆̆ın progresyonu ve hasta prognozu ile ilişkili olduğu bulunmuştur (45). Literatürde CDH1, RASSF1A gibi genlerdeki hipermetilasyonun yüksek tümör sınifı ile APAF-1, IGFBP3, p16INK4A, p14ARF metilasyonunun tümör rekürrensi ile RUNX-3, Myopodin metilasyonunun da tümör progresyonu ile ilişkili olabileceği gösterilmiştir $(46,47,48,49,50,51)$. Bir başka tümör süpresör gen olan ITIH5 'in promoter hipermetilasyonunun, ITIH-5 mRNA down regülasyonuna yol açarak özellikle pT1 tümörlerde erken relaps ve progresyon ile ilişkili olduğu gösterilmiştir (52). Yine kasa invaziv mesane tümöründe, DNMT1 ve DNMT3a'nın anlamlı olarak indüksiyonu, anti-proliferatif bir gen olan BTG2 ekspresyonunu 
inhibe etmek yoluyla invaziv kanser proliferasyonunda aktif rolü olduğunu göstermiştir (53).

Mesane tümöründe histon modifikasyonlarının prognostik değerine bakıldığında, düșük malign potansiyelli papiller ürotelyal neoplazmda azalmış H3K9ac seviyesi artmış rekürrens eğilimi ile ilişkili olarak bulunmuştur (54). Bunun aksine, histon H2AX'ın (H2AXS139Ph) serin 139'unun fosforilasyonu transüretral rezeksiyon (TUR) sonrası düşük rekürrens riski ile ilişkilidir (55). Farklı evrelerdeki mesane tümörlü hastaların dokularının incelendiği yakın zamandaki bir çalışma H3K4me1, H4K20me1, H4K20me2 ve H4K20me3 immünekspresyon düzeylerinin ileri patolojik evre ile korele olduğunu; H4K20me3'ün kas invaziv mesane tümörlü hastalarda hastalığa spesifik sağkalımın bağımsız prognostik prediktörü olduğu gösterilmiştir (56).

MikroRNA değişikliklerinden mikroRNA-129, mikroRNA-133b ve mikroRNA-518c'nin kötü prognozla ilişkili olduğu gösterilmiş̧tir (57). Yine artmış mikroRNA-452 ve mikroRNA-452 düzeylerinin lenf nodu metastazı olan mesane tümörlü hastalarda görülmekte olduğu ve kötü prognozla ilişkisi saptanmıştır (58).

Epigenetik çalışmalar, mesane tümörlerinin non-invaziv olarak saptanması ve prognozunun sağılıkı bir şekilde öngörülebilmesi açısından umut verici görünmektedir. Hücre döngüsünü kontrol eden proteinler, anjiyogeneze etki eden moleküller ve genetik değişimler, gelecekte mesane kanserinin doğal seyrini ve tümörün uygulanacak tedavilere vereceği yanıtı daha güvenilir biçimde öngörmede rol oynayabilirler.

Hedefe yönelik ilaç tedavilerinin yoğun şekilde araştırıldığı ve klinik kullanıma girmeye başladığı bu dönemde mesane kanseri hastalarında tümörlerin moleküler ve genetik özelliklerinin belirlenmesi çok önemlidir. Böylelikle mesane kanserinin doğal seyri ve uygulanan tedavilerin yanıtını öngörebilecek yeni belirteçler günlük kullanıma girebilecektir. Ayrıca gelecekte tümörün rekürrens, progresyon ve hastalığın prognozunu öngörebilecek uygun gen kombinasyonlarının belirlenebilmesi halinde, metilasyon sonucu inaktive hale geçen genler yeniden aktive hale dönüştürülüp hastalığın tedavisine de olumlu katkılar sağlanabilecektir.

Etik

Hakem Değerlendirmesi: Editörler kurulu tarafından değerlendirilmiştir.

Yazarılık Katkıları

Konsept: Cavit Can, Dizayn: Cavit Can, Veri Toplama veya İşleme: Ali Ülgen, Analiz veya Yorumlama: Ata Özen, Literatür Arama: Ali Ülgen, Yazan: Ata Özen.

Çıkar Çatışması: Yazarlar bu makale ile ilgili olarak herhangi bir çıkar çatışması bildirmemiştir.

Finansal Destek: Çalışmamız için hiçbir kurum ya da kişiden finansal destek alınmamıştır.

\section{Kaynaklar}

1. MacVicar AD. Bladder cancer staging. BJU Int 2000;86(Suppl 1):111-122.

2. Messing EM, Young TB, Hunt VB, et al. Comparison of bladder cancer outcome in men undergoing hematuria home screning versus those with standard clinical presentations. Urology 1995;45:387-396.

3. Hanahan D, Weinberg RA. The hallmarks of cancer. Cell 2000;100:57-70.

4. Baffa R, Letko J, McClung C, et al. Molecular genetics of bladder cancer: targets for diagnosis and therapy. J Exp Clin Cancer Res 2006;25:145-160.
5. Lopez-Beltran A, Sauter G, Gasser T, et al. Infiltrating urothelial carcinoma. In: Eble NJ, Sauter G, Epstein JI, editors. World Health Organization Classification of Tumours, Tumours of the Urinary System and Male Genital Organs. France: Lyon; 2004. p. 90-109.

6. Esteller M. Epigenetics in cancer. N Engl J Med 2008;358:1148-1159.

7. Feinberg AP, Tycko B. The history of cancer epigenetics. Nat Rev Cancer 2004;4:143-153.

8. Jerenimo $C$, Henrique R. Epigenetic biomarkers in urological tumors: A systematic review. Cancer Letters 2014;342:264-274.

9. Hoffman AM, Cairns P. Epigenetics of kidney cancer and bladder cancer. Epigenomics 2011;3:19-34.

10. Harb-De La Rosa A, Acker M, Kumar Ra, Manoharan M. Epigenetics applicationin the diagnosis and treatment of bladder cancer. Can I Urol 2015;22:7947-7951.

11. Goldberg $A D$, Allis $C D$, Bernstein E. Epigenetics: a landscape takes shape. Cell 2007;128:635-638.

12. Lopez-Serra L, Esteller M. Proteins that bind methylated DNA and human cancer: reading the wrong words. British J Cancer 2008;98:1881-1885.

13. Wang $X$, Zhang $L$, Ding $N$, et al. Identification and characterization of DNAzymes targeting DNA methyltransferaze I for suppressing bladder cancer proliferation. Biochem Biophys Res Commun 2015;461:329-333.

14. Vaissière T, Sawan C, Herceg Z. Epigenetic interplay between histone modifications and DNA methylation in gene silencing. Mut Res 2008;659:40-48.

15. Clark SJ, Melki J. DNA methylation and gene silencing in cancer: which is the guilty party? Oncogene. 2002;21:5380-5387.

16. ScaranoMI, Strazzullo M, Matarazzo MR, D’Esposito M. DNA methylation 40 years later: its role in human health and disease. J Cell Physiol 2005;204:21-35.

17. Attwood JT, Yung RL, Richardson BC. DNA methylation and the regulation of gene transcription. Cell Mol Life Sci 2002;59:241-257.

18. Tost J. DNA Methylation : Methods and Protocols 2nd ed. New York: Humana Press; 2009.

19. Sharma S, Kelly TK, Jones PA. Epigenetics in cancer. Carcinogenesis 2010;31:27-36.

20. Feinberg $A B$, Ohlsson R, Henikoff $S$. The epigenetic progenitor origin of human cancer. Nat Rev Genet 2006;7:21-33.

21. Coolen MW, Stirzaker C, Song JZ, et al. Consolidation of the cancer genome into domains of repressive chromatin by long-range epigenetic silencing (LRES) reduces transcriptional plasticity. Nat Cell Biol 2010;12:235-246.

22. Phé $V$, Cussenot $O$, Rouprêt $M$. Interest of methylated genes as biomarkers in urothelial cell carcinomas of the urinary tract. BJU Int 2009;104:896-901.

23. Kouzarides T. Chromatin modifications and their function. Cell 2007; 128:693-705.

24. Mellor J. The dynamics of chromatin remodeling at promoters. Mol Cell 2005;19:147-157.

25. Lennartsson A, Ekwall K. Histone modification patterns and epigenetic codes. Biochim Biophys Acta 2009;1790:863-868.

26. Bhaumik SR, Smith E, Shilatifard A. Covalent modifications of histones during development and disease pathogenesis. Nat Struct Mol Biol 2007; 14:1008-1016.

27. Guil S, Esteller M. DNA methylomes, histone codes and miRNAs: tying it all together. Int J Biochem. Cell Biol 2009;41:87-95.

28. Garzon R, Calin GA, Croce CM. MicroRNAs in Cancer. Ann Rev Med 2009;60:167-179.

29. Shenouda SK, Alahari SK. MicroRNA function in cancer: oncogene or a tumor suppressor? Cancer Metastasis Rev 2009;28:369-378.

30. Dudziec E, Miah S, Choudhry HM, et al. Hypermethylation of $\mathrm{CpG}$ islands and shores around specific microRNAs and mirtrons is 
associated with the phenotype and presence of bladder cancer. Clin Cancer Res 2011;17:1287-1296.

31. Garibyan L, Avashia N. Polymerase chain reaction. J Invest Dermatol 2013;133:6.

32. Andres G, Ashour N, Sanchez Chapado M, et al. The study of DNA methylation in urological cancer:present and future. Actas Urol Esp 2013;37:368-375.

33. Renard I, Joniau S, van Cleynenbreugel B, et al. Identification and validation of the methylated TWIST1 and NID2 genes through realtime methylation-specific polymerase chain reaction assays for the noninvasive detection of primary bladder cancer in urine samples. Eur Urol 2010;58:96-104.

34. Chung W, Bondaruk J, Jelinek J, et al. Detection of bladder cancer using novel DNA methylation biomarkers in urine sediments. Cancer Epidemiol Biomarkers Prev 2011;20:1483-1491.

35. Chan MW, Chan LW, Tang NL, et al. Hypermethylation of multiple genes in tumor tissues and voided urine in urinary bladder cancer patients. Clin Cancer Res 2002;8:464-470.

36. Dulaimi E, Uzzo RG, Greenberg RE, et al. Detection of bladder cancer in urine by a tumor suppressor gene hypermethylation panel. Clin Cancer Res 2004;10:1887-1893.

37. Costa VL, Henrique $R$, Danielsen $S A$, et al. Three epigenetic biomarkers, GDF15, TMEFF2, and VIM, accurately predict bladder cancer from DNA-based analyses of urine samples. Clin Cancer Res 2010;16:5842-5851.

38. Patchsung M, Broonla C, Amnattrakul P, et al. Long interspersed nuclear element-1 hypomethylation and oxidative stress: correlation and bladder cancer diagnostik potential. Plos One 2012;7:37009.

39. Hanke M, Hoefig $\mathrm{K}$, Merz $\mathrm{H}$, et al. A robust methodology to study urine microRNA as tumor marker: microRNA-126 and microRNA-182 are related to urinary bladder cancer. Urol Oncol 2010;28:655-661.

40. Mahdavinezhad A, Mousavi-Bahar SH, Poorolajal J, et al. Evaluation of miR-141, miR-200c, miR-30b Expression and Clinicopathological Features of Bladder Cancer. Int J Mol Cell Med 2015;4:32-39.

41. Raman JD, Mongan NP, Tickoo SK, et al. Increased expression of the polycomb group gene, EZH2, in transitional cell carcinoma of the bladder. Clin Cancer Res 2005;11:8570-8576.

42. Hayami S, Kelly JD, Cho HS, et al. Overexpression of LSD1 contributes to human carcinogenesis through chromatin regulation in various cancers. Int J Cancer 2011;128:574-586.

43. Wolff EM, Liang G, Cortez CC, et al. RUNX-3 methylation reveals that bladder tumours are older in patients with a history of smoking. Cancer Res 2008;68:6208-6214.

44. Kim WJ, Kim EJ, Jeong P, et al. RUNX3 inactivation by point mutations and aberrant DNA methylation in bladder tumors. Cancer Res 2005;65:9347-9354.
45. Hoque MO, Begum S, Brait $M$, et al. Tissue inhibitor of metalloproteinases-3 promoter methylation is an independent prognostic factor for bladder cancer. J Urol 2008;179:743-747.

46. Horikawa $Y$, Sugano K, Shigyo M, et al. Hypermethylation of an E-cadherin $(\mathrm{CDH}-1)$ promoter region in hihg grade transitional cell carcinoma of the bladder comprising carcinoma in situ. J Urol 2003;169:1541-1545.

47. Maruyama R, Toyooka S, Toyooka KO, et al. Aberrant promoter methylation profile of bladder cancer and its relationship to clinicopathological features. Cancer Res 2001;61:8659-8663.

48. Christoph F, Weikert S, Kempkensteffen C, et al. Regularly methylated novel pro-apoptotic genes associated with recurrence in transitional cell carcinoma of the bladder. Int J Cancer 2006;119:1396-1402.

49. Kawamoto K, Enokida H, Gotanda T, et al. p16INK4a and p14ARF methylation as a potential biomarker for human bladder cancer. BBRC 2006;339:790-796.

50. Kim EJ, Kim YJ, Jeong P, et al. Methylation of the RUNX-3 promoter as a potential prognostic marker for bladder tumor. J Urol 2008;180:1141-1145.

51. Alvarez-Múgica M, Cebrian V, Fernández-Gómez JM, et al. Myopodin methylation is associated with clinical outcome in patients with T1G3 bladder cancer. J Urol 2010;184:1507-1513.

52. Rose M, Gaisa NT, Anyony P, et al. Epigenetic inactivation of ITIH5 promotes bladder cancer progression and predicts early relapse of pT1 high-grade urothelial tumours. Carcinogenesis. 2014;35:727-736.

53. Devanand P, Kim SI, Choi YW, et al. Inhibition of bladder cancer invasion by $\mathrm{Sp} 1$-mediated BTG2 expression via inhibition of DNA methyltransferase 1. FEBS J 2014; 281:5581-5601.

54. Barbisan F, Mazzucchelli R, Santinelli A, et al. Immunohistochemical evaluation of global DNA methylation and histone acetylation in papillary urothelial neoplasm of low malignant potential. Int J Immunopathol Pharmacol 2008;21:615-623.

55. Cheung WL, Albadine R, Chan T, et al. Phosphorylated H2AX in noninvasive low grade urothelial carcinoma of the bladder: correlation with tumor recurrence. J Urol 2009;181:1387-1392.

56. Schneider AC, Heukamp LC, Rogenhofer S, et al. Global histone H4K20 trimethylation predicts cancer-specific survival in patients with muscle-invasive bladder cancer. BJU Int 2011;108:290-296.

57. Dyrskjot L, Ostenfeld MS, Bramsen JB, et al. Genomic profiling of microRNAs in bladder cancer: miR-129 is associated with poor outcome and promotes cell death in vitro. Cancer Res 2009;69:4851-4860.

58. Veerla $S$, Lindgren $D$, Kvist A, et al. MiRNA expression in urothelial carcinomas: important roles of miR-10a, miR-222, miR-125b, miR-7 and miR-452 for tumor stage and metastasis, and frequent homozygous losses of miR-31. Int J Cancer 2009;124:2236-2242. 